\title{
Generation and hydrolysis of $N$-acyloxazolinium salts allowing regiospecific acylation of chiral amino alcohols
}

\author{
R. Alan Aitken*, Alexandra M. Z. Slawin and Andrew Wilson \\ EaStCHEM School of Chemistry, University of St Andrews, \\ North Haugh, St Andrews, Fife, KY16 9ST, United Kingdom; e-mail: raa@st-and.ac.uk \\ Submitted March 4, 2020
}<smiles>[R]CCCC(=O)OC[C@H]([R])NC([R])=O</smiles>

In an attempt to form 2-alkylidene-1,3-oxazolidines, chiral 2-oxazolines have been $N$-alkylated and $N$-acylated. Two new $N$ methyloxazolinium salts have been prepared and characterised but base treatment resulted in their decomposition. In contrast, attempts to isolate three $N$-benzoyloxazolinium salts gave the products of their ring hydrolysis: unsymmetrically diacylated amino alcohols whose structure was confirmed by x-ray diffraction in one case. Overall the method allows stepwise regiospecific $N, O$-diacylation of 1,2-amino alcohols.

Keywords: amino alcohols, acylation, oxazolines, oxazolinium salts, hydrolysis

We recently reported that the thermal isomerization of 2benzylidene-1,3-dioxolane (1) to give the $\gamma$-lactone 2 (Scheme 1), which was previously carried out by gas-phase flow pyrolysis at atmospheric pressure, ${ }^{1}$ could be achieved more efficiently using conditions of flash vacuum pyrolysis $(\mathrm{FVP}){ }^{2}$ In the same paper 1,3-oxathiolane derivatives including the sulfone analogue of $\mathbf{1}$ were also examined but in these cases the pyrolysis took a different course. ${ }^{2} \mathrm{We}$ were interested to examine the nitrogen analogues $\mathbf{3}$ since, if these reacted in the same way as $\mathbf{1}$, they would give the more useful $\gamma$-lactams $\mathbf{4}$ with the added advantage that a stereogenic centre at the 4-position in the starting oxazolidines would likely appear with retention of configuration at $\mathrm{C}-5$ in the product and induce stereoselectivity at the newly formed C-3 centre.

Scheme 1<smiles>O=C1OCCC1c1ccccc1</smiles><smiles></smiles>

We envisaged that the required 2alkylideneoxazolidines 7 could be prepared starting from the readily available oxazolines 5 by $N$-alkylation to give salts 6 followed by base treatment (Scheme 2). Literature precedent for this is provided by sodium hydride treatment of 2,3,4,4-tetramethyloxazolinium iodide to give the 2- methylene compound, ${ }^{3}$ although this was noted to be extremely susceptible to acid-catalysed hydrolysis, a feature also observed for similar $N$-methyloxazolinium salts in earlier work. ${ }^{4}$

Scheme 2<smiles>[R]CCOC(=N)C[R4]</smiles>

We started by converting the two readily available chiral oxazolines $\mathbf{5 a}$ and $\mathbf{5 b}$, prepared by reaction of ethyl acetimidate hydrochloride with $(S)$-phenylalaninol and $(S)$ valinol respectively, ${ }^{5}$ into the corresponding $N$ methyloxazolinium salts $\mathbf{6 a}$ and $\mathbf{6 b}$. Treatment with iodomethane in THF at room temperature in the dark gave the required salts in low to moderate yield as colourless crystals (Scheme 3). It was noticeable that the more sterically hindered compound $\mathbf{5 b}$ reacted more slowly and to give a lower yield of $\mathbf{6}$ than $\mathbf{5 a}$. These gave the expected HRMS and spectroscopic properties including significant movement to higher chemical shift in the ${ }^{1} \mathrm{H}$ NMR signals for the ring hydrogens and 2-methyl group as compared to the starting oxazolines. In the ${ }^{13} \mathrm{C}$ NMR spectra the most prominent change was an increase in the chemical shift for C-2 from 164 for 5 to 176 for $\mathbf{6}$. 
Scheme 3<smiles>CC1=N[C@H](Cc2ccccc2)C[C@H]1Cc1ccccc1</smiles>

Unfortunately, treatment of the salts $\mathbf{6}$ with sodium hydride in dry THF according to the literature method for the corresponding 4,4-dimethyl compounds, ${ }^{3}$ led, after addition of petroleum and removal of the resulting precipitate of sodium iodide, to solutions of compounds 7 that were too reactive to handle using normal methods and polymerised. In order to obtain less reactive and more easily handled 2-alkylidene-1,3-oxazolidines 7, we decided to move to $N$-benzoyl oxazolinium salts (Scheme 4) since these are a well known class of stable compounds, ${ }^{6}$ and are reported to undergo facile deprotonation using triethylamine, ${ }^{7}$ although there are a number of possible complicating side-reactions of the 2-methylene-1,3oxazolidines in the presence of excess acylating agent. ${ }^{8}$

Scheme 4<smiles>[R1]CC1=N[C@@H]([R2])CO1</smiles>

5<smiles>[R1]CC1=[N+](C(=O)c2ccccc2)[C@@H]([R2])CO1</smiles>

6<smiles>[R]C=C1OC[C@@H]([R])N1C(=O)Pc1ccccc1</smiles>

Following the literature method, ${ }^{7}$ oxazoline 5a was stirred in toluene with one equivalent of triethylamine while one equivalent of benzoyl chloride was added dropwise. After $3 \mathrm{~h}$ the solution was filtered and evaporated to give, after trituration with diethyl ether, a solid that turned out to be the hydrolysis product $\mathbf{8 a}$ (Scheme 5).
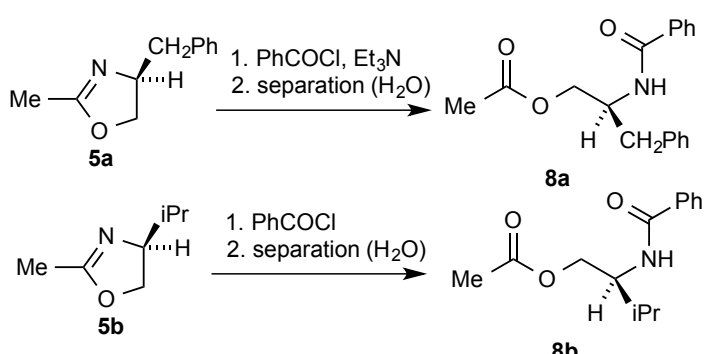

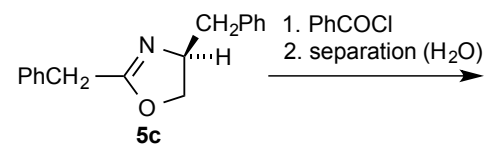<smiles>O=C(Cc1ccccc1)OC[C@H](Cc1ccccc1)NC(=O)c1ccccc1</smiles>

$8 c$

It seems likely that the desired $N$-benzoyloxazolinium salt has been formed but, rather than undergo deprotonation to form the alkylidene compound 7 , it has undergone hydrolysis in the course of isolation to give the $\mathrm{N}$-benzoyl$O$-acetylphenylalaninol product 8a. This compound was first prepared and characterised spectroscopically in $1992,{ }^{9}$ but it was recorded in the literature some time earlier ${ }^{10}$ as a derivative of $N$-benzoylphenylalaninol occurring as a natural product in the leaves of Alangium lamarckii. More recently it has been mentioned under the trivial name "saropeptate", together with a range of steroidal components, as a constituent of Pupalia lappacea, a plant important in Ayurvedic medicine. ${ }^{11}$

Although compound 8a showed excellent agreement with the literature spectroscopic data, ${ }^{9}$ it was obtained in well-formed crystals so we took the chance to confirm its structure using X-ray diffraction (Figure 1). As might be expected, the presence of a secondary amide function leads to hydrogen bonding and the crystal structure shows chains of molecules formed by the amide carbonyl $\mathrm{C}(1)-\mathrm{O}(1)$ to $\mathrm{N}(2)-\mathrm{H}(2)$ hydrogen bonding (Figure 2, Table 1).

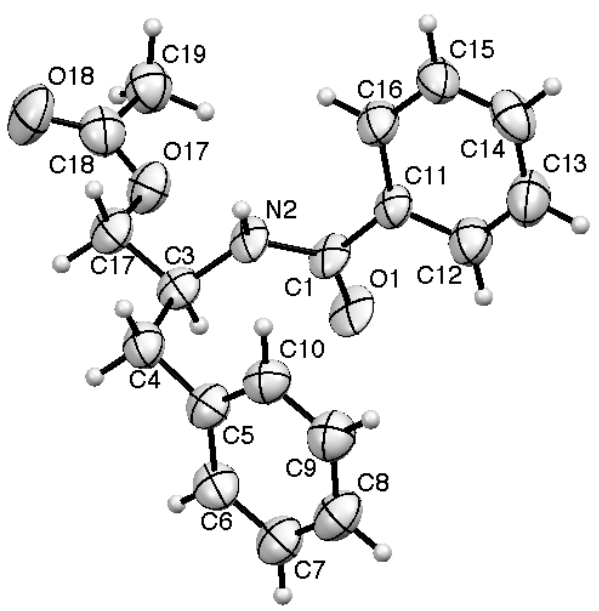

Figure 1. Molecular structure of compound 8a with atoms represented by thermal vibration ellipsoids at the $50 \%$ probability level. 


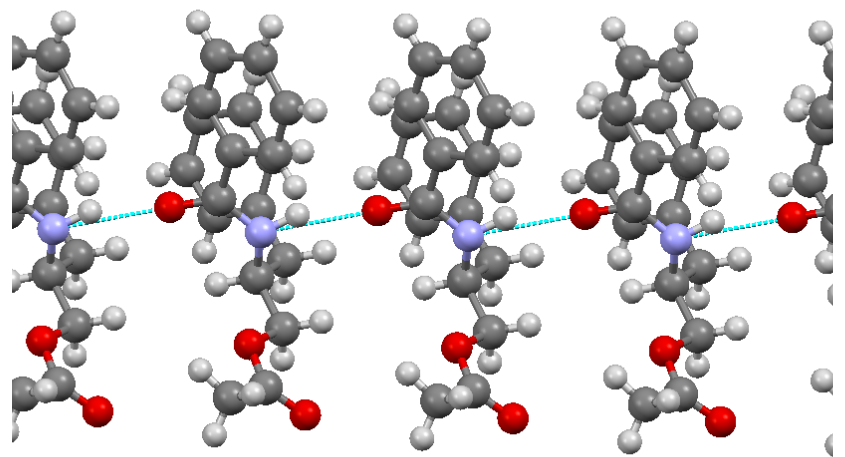

Figure 2. Hydrogen bonding pattern in crystal structure of $\mathbf{8 a}$ viewed perpendicular to the $a$ axis.

Table 1. Hydrogen bonding parameters for $\mathbf{8 a}\left(\AA,^{\circ}\right)$

\begin{tabular}{cllll}
\hline D-H...A & D-H & H...A & D...A & D-H...A \\
\hline $\mathrm{N}(2)-\mathrm{H}(2) \ldots \mathrm{O}(1)$ & $0.98(5)$ & $1.94(5)$ & $2.870(7)$ & $157(6)$ \\
\hline
\end{tabular}

Having established that hydrolysis of the $\mathrm{N}$ benzoyloxazolidinium salts rather than any base-induced process was involved in the formation of $\mathbf{8 a}$, the oxazolines $\mathbf{5 b}$ and $\mathbf{5 c}$ were subjected to reaction with benzoyl chloride in the absence of triethylamine and in each case the product recovered after evaporation and trituration was the hydrolysis product $\mathbf{8}$ (Scheme 5). Both $N$-benzoyl- $O$ acetylvalinol $\mathbf{8 b}$ and $\mathrm{N}$-benzoyl- $\mathrm{O}$-phenylacetylphenylalan-inol 8c are apparently new compounds and gave spectroscopic data in good agreement with the proposed structures and with that of $\mathbf{8 a}$. The 2-benzyloxazoline $\mathbf{5 c}$ took much longer to react than 2-methyloxazolines 5a and $\mathbf{5 b}$, presumably due to the electron-withdrawing phenyl group making it less nucleophilic.

Although it has clearly been arrived at by accident rather than design, the overall formation of the selectively diacylated amino alcohols 8 starting from compounds of general structure $\mathbf{9}$ is a rather useful transformation. Recent studies have proposed various catalysts to bring about enzyme-like selectivity in such reactions. ${ }^{12}$ In this case the general method for overall conversion of an amino acidderived chiral amino alcohol 9 into the diacylated derivative $\mathbf{1 0}$ involves formation of the oxazoline $\mathbf{5}$ with the ultimate $O$-substituent at the 2-position, $\mathrm{N}$-acylation with the ultimate $N$-substituent and hydrolytic isolation to give the product $\mathbf{1 0}$ (Scheme 6)

Scheme 6

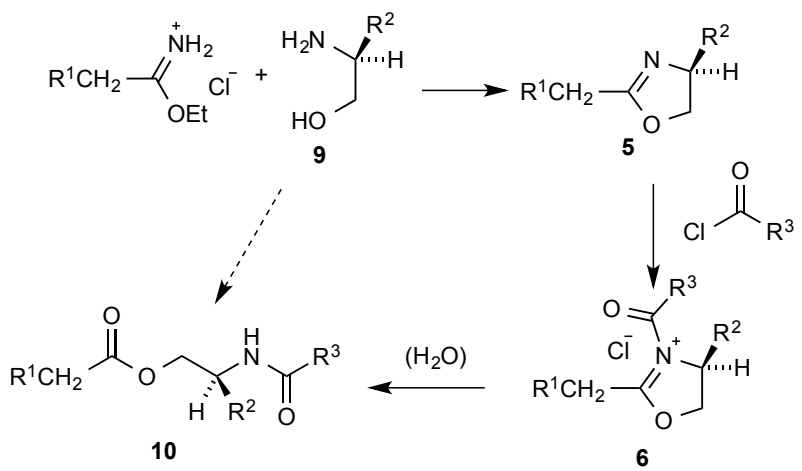

In contrast to $N$-methyloxazolinium salts which were easily prepared and isolated, the $N$-benzoyloxazolinium salts proved to be much more reactive and could not be isolated as such. However the isolation of their hydrolysis products in low to moderate yield does form the basis of a useful overall synthetic transformation.

\section{EXPERIMENTAL}

General Experimental Details. Melting points were determined using a Gallenkamp 50W melting point apparatus and are uncorrected. IR spectra were measured using the ATR techique on a Shimadzu IRAffinity $1 \mathrm{~S}$ instrument. NMR spectra were recorded on solutions in $\mathrm{CDCl}_{3}$ at $400 \mathrm{MHz}$ for ${ }^{1} \mathrm{H}$ and at 100 or $125 \mathrm{MHz}$ for ${ }^{13} \mathrm{C}$ using Bruker AV400 or AVIII 500 spectrometers. HRMS measurements were made using a Micromass LCT spectrometer with electrospray ionisation. THF was dried over sodium wire.

Preparation of starting oxazolines. (S)-4-Benzyl-2methyloxazoline 5a and (S)-4-isopropyl-2-methyloxazoline 5b were prepared from ethyl acetimidate hydrochloride by respective reaction with $(S)$-phenylalaninol and $(S)$-valinol as previously reported, ${ }^{5}$ while $(S)$-2,4-dibenzyloxazoline $\mathbf{5 c}$ was similarly prepared, ${ }^{13}$ using ethyl 2-phenylacetimidate hydrochloride ${ }^{14}$ and $(S)$-phenylalaninol.

(S)-4-Benzyl-2,3-dimethyloxazolinium iodide (6a). A solution of oxazoline 5a $(2.0 \mathrm{~g}, 11.4 \mathrm{mmol})$ in dry THF $(2.5 \mathrm{ml})$ was stirred at room temperature while iodomethane $(0.87 \mathrm{ml}, 1.99 \mathrm{~g}, 14 \mathrm{mmol})$ was added and the resulting mixture was stirred in the dark for $15 \mathrm{~h}$. The resulting solid was filtered off and dried. Yield $1.65 \mathrm{~g}$ (47\%), colourless crystals, mp $176-178{ }^{\circ} \mathrm{C}$. IR spectrum (ATR), $v, \mathrm{~cm}^{-1}: 1668,1483,1279,1033,984,758,704 .{ }^{1} \mathrm{H}$ NMR spectrum, $\delta$, ppm $(J, \mathrm{~Hz}): 2.59(3 \mathrm{H}, \mathrm{s}, 2-\mathrm{Me}) ; 3.20$ $\left(1 \mathrm{H}\right.$, half $\mathrm{AB}$ pattern of $\left.\mathrm{d}, J=14.4, J=7.6, \mathrm{PhCH}_{2}\right) ; 3.35$ $\left(1 \mathrm{H}\right.$, half AB pattern of d, $\left.J=14.4, J=4.8, \mathrm{PhCH}_{2}\right) ; 3.51$ $(3 \mathrm{H}, \mathrm{s}, 3-\mathrm{Me}) ; 4.68(1 \mathrm{H}$, half $\mathrm{AB}$ pattern of $\mathrm{d}, J=9.0, J=$ $\left.6.4, \mathrm{OCH}_{2}\right) ; 5.08-5.16(1 \mathrm{H}, \mathrm{m}, 4-\mathrm{H}) ; 5.19(1 \mathrm{H}$, half $\mathrm{AB}$ pattern of d, $\left.J=10.3, J=9.0, \mathrm{OCH}_{2}\right) ; 7.23-7.27(2 \mathrm{H}, \mathrm{m}$, $\mathrm{Ph}) ; 7.30-7.41(3 \mathrm{H}, \mathrm{m}, \mathrm{Ph}) .{ }^{13} \mathrm{C}$ NMR spectrum, $\delta$, ppm: 15.3 (2-Me); 34.5 (3-Me); $36.3\left(\mathrm{PhCH}_{2}\right) ; 64.6(4-\mathrm{CH}) ; 75.4$ $\left(\mathrm{CH}_{2} \mathrm{O}\right) ; 128.1(\mathrm{Ar} \mathrm{CH}) ; 129.1(\mathrm{Ar} 2 \mathrm{CH}) ; 129.4(\mathrm{Ar} 2 \mathrm{CH})$; 133.0 (Ar C); 176.7 (C-2). Found, $m / z: 190.1224$ [M-I] $]^{+}$. $\mathrm{C}_{12} \mathrm{H}_{16}$ NO. Calculated, $m / z$ : 190.1232 .

(S)-4-Isopropyl-2,3-dimethyloxazolinium iodide (6b). A solution of oxazoline $\mathbf{5 b}(1.40 \mathrm{~g}, 11.0 \mathrm{mmol})$ in dry THF $(2.5 \mathrm{ml})$ was stirred at room temperature while iodomethane $(0.87 \mathrm{ml}, 1.99 \mathrm{~g}, 14 \mathrm{mmol})$ was added and the resulting mixture was stirred in the dark for $72 \mathrm{~h}$. The resulting solid was filtered off and dried. Yield $0.69 \mathrm{~g}$ (23\%), colourless crystals, mp $143-144{ }^{\circ} \mathrm{C}$. IR spectrum (ATR), v, cm ${ }^{-1}: 1675,1483,1276,1039,987,925,830 .{ }^{1} \mathrm{H}$ NMR spectrum, $\delta, \operatorname{ppm}(J, \mathrm{~Hz}): 0.97(3 \mathrm{H}, \mathrm{d}, J=6.9$ $\mathrm{CHMe}) ; 1.04(3 \mathrm{H}, \mathrm{d}, J=6.9, \mathrm{CHMe}) ; 2.32(1 \mathrm{H}, \mathrm{m}$, $\left.\mathrm{CHMe}_{2}\right) ; 2.65(3 \mathrm{H}, \mathrm{s}, 2-\mathrm{Me}) ; 3.44(3 \mathrm{H}, \mathrm{s}, 3-\mathrm{Me}) ; 4.62(1 \mathrm{H}$, half $\mathrm{AB}$ pattern of $\left.\mathrm{d}, J=9.2, J=6.8, \mathrm{OCH}_{2}\right) ; 4.70-4.80$ $(1 \mathrm{H}, \mathrm{m}, 4-\mathrm{H}) ; 5.27(1 \mathrm{H}$, half AB pattern of d, $J=11.0, J=$ 9.2, $\left.\mathrm{OCH}_{2}\right) .{ }^{13} \mathrm{C} \mathrm{NMR}$ spectrum, $\delta, \mathrm{ppm}: 14.9(\mathrm{CHMe})$; 15.1 (CHMe); 17.9 (2-Me); $26.5\left(\mathrm{CHMe}_{2}\right) ; 34.0$ (3- $\left.\mathrm{Me}\right)$; $68.6(4-\mathrm{CH}) ; 72.0\left(\mathrm{CH}_{2} \mathrm{O}\right) ; 176.8(\mathrm{C}-2)$. Found, $\mathrm{m} / z$ : $142.1223[\mathrm{M}-\mathrm{I}]^{+} . \mathrm{C}_{8} \mathrm{H}_{16} \mathrm{NO}$. Calculated, $\mathrm{m} / z$ : 142.1232. 
(S)-2-Benzoylamino-3-phenylpropyl acetate (8a). A solution of oxazoline $5 \mathbf{a}(0.35 \mathrm{~g}, 2 \mathrm{mmol})$ and triethylamine $(0.33 \mathrm{ml}, 0.25 \mathrm{~g}, 2.4 \mathrm{mmol})$ in dry toluene $(60 \mathrm{ml})$ was stirred at RT while benzoyl chloride $(0.23 \mathrm{ml}, 0.28 \mathrm{~g}, 2$ mmol) was added dropwise. After stirring for $3 \mathrm{~h}$, the mixture was filtered and evaporated. The residue was triturated with diethyl ether to give the product. Yield 0.18 g (31\%), colourless crystals, mp $124-126^{\circ} \mathrm{C}$ (lit., ${ }^{9} 125-127$ $\left.{ }^{\circ} \mathrm{C}\right) .{ }^{1} \mathrm{H}$ NMR spectrum, $\delta$, ppm $(J, \mathrm{~Hz}): 2.10(3 \mathrm{H}, \mathrm{s}$, COMe); $2.91(1 \mathrm{H}$, half AB pattern of d, $J=13.6, J=8.0$, $\left.\mathrm{CH}_{2} \mathrm{Ph}\right) ; 3.06(1 \mathrm{H}$, half AB pattern of d, $J=13.6, J=5.8$, $\left.\mathrm{CH}_{2} \mathrm{Ph}\right) ; 4.14(1 \mathrm{H}$, half AB pattern of d, $J=11.6, J=3.8$, $\left.\mathrm{CH}_{2} \mathrm{O}\right) ; 4.23(1 \mathrm{H}$, half $\mathrm{AB}$ pattern of $\mathrm{d}, J=11.6, J=6.0$, $\left.\mathrm{CH}_{2} \mathrm{O}\right) ; 4.60-4.70(1 \mathrm{H}, \mathrm{m}, \mathrm{C} \underline{\mathrm{HNH}}) ; 6.41(1 \mathrm{H}, \mathrm{br} \mathrm{d}, J=8.0$, $\mathrm{NH}) ; 7.20-7.30(2 \mathrm{H}, \mathrm{m}) ; 7.30-7.34(3 \mathrm{H}, \mathrm{m}) ; 7.40-7.45$ $(2 \mathrm{H}, \mathrm{m}) ; 7.48-7.52(1 \mathrm{H}, \mathrm{m}) ; 7.70-7.73(2 \mathrm{H}, \mathrm{m}) .{ }^{13} \mathrm{C} \mathrm{NMR}$ spectrum, $\delta$, ppm: $20.9(\mathrm{Me}) ; 37.5\left(\underline{\mathrm{CH}}_{2} \mathrm{Ph}\right) ; 50.3(\underline{\mathrm{CHN}})$; $64.8\left(\mathrm{CH}_{2} \mathrm{O}\right) ; 126.8(\mathrm{Ar} \mathrm{3CH}) ; 128.6(\mathrm{Ar} 2 \mathrm{CH}) ; 128.7(\mathrm{Ar}$ $2 \mathrm{CH}) ; 129.3$ (Ar 2CH); 131.6 (Ar CH); 134.3 (Ar C); 136.9 (Ar C); 167.0 (NCO); 171.5 (OCO). Both ${ }^{1} \mathrm{H}$ and ${ }^{13} \mathrm{C}$ NMR spectra showed excellent agreement with literature data. ${ }^{9}$

X-ray structure of 8a. Crystal data: $\mathrm{C}_{18} \mathrm{H}_{19} \mathrm{NO}_{3}, M=$ 297.35, colourless needle, crystal dimensions $0.12 \times 0.01 \times$ $0.01 \mathrm{~mm}$, orthorhombic, space group $P 22_{1} 2_{1} 2_{1}, a=$ 5.0182(4), $b=16.208(3), c=19.498(3) \AA, V=1585.9(4)$ $\AA^{3}, Z=4, D_{c}=1.245 \mathrm{Mg} \mathrm{m}^{-3}, T=125 \mathrm{~K}, R=0.1219, R_{w}=$ 0.3082 for 1890 reflections with $I>2 \sigma(I)$ and 203 variables. Data were collected on a Rigaku XtaLAB P200 system using graphite-monchromated $\mathrm{Cu}-\mathrm{K}_{a}$ radiation, $\lambda=1.54187$ $\AA$ and have been deposited at the Cambridge Crystallographic Data Centre as CCDC 1861267. The data can be obtained free of charge from the Cambridge Crystallographic Data Centre via www.ccdc.cam.ac.uk/getstructures

(S)-2-Benzoylamino-3-methylbutyl acetate (8b). A solution of oxazoline $5 \mathbf{b}(0.51 \mathrm{~g}, 4 \mathrm{mmol})$ in dry toluene $(120 \mathrm{ml})$ was stirred at RT while benzoyl chloride $(0.46 \mathrm{ml}$, $0.56 \mathrm{~g}, 4 \mathrm{mmol}$ ) was added dropwise. After stirring for $3 \mathrm{~h}$, the mixture was evaporated and the residue was triturated with diethyl ether to afford the title compound as colourless crystals (77 mg, 7\%), mp $74-76{ }^{\circ} \mathrm{C} .{ }^{1} \mathrm{H}$ NMR spectrum, $\delta$, $\operatorname{ppm}(J, \mathrm{~Hz}): 1.018(3 \mathrm{H}, \mathrm{d}, J=6.8, \mathrm{CHMe}) ; 1.022(3 \mathrm{H}, \mathrm{d}, J$ $=6.8, \mathrm{CHMe}) ; 1.95\left(1 \mathrm{H}\right.$, octet, $\left.J=6.8, \mathrm{CHMe}_{2}\right) ; 2.06(3 \mathrm{H}$, $\mathrm{s}, \mathrm{COMe}) ; 4.15(1 \mathrm{H}$, half $\mathrm{AB}$ pattern of $\mathrm{d}, J=11.6, J=3.6$, $\left.\mathrm{CH}_{2} \mathrm{O}\right) ; 4.20-4.30(1 \mathrm{H}, \mathrm{m}, \mathrm{CHNH}) ; 4.39(1 \mathrm{H}$, half $\mathrm{AB}$ pattern of d, $\left.J=11.6, J=6.6, \mathrm{CH}_{2} \mathrm{O}\right) ; 6.24(1 \mathrm{H}$, br d, $J=$ $8.4, \mathrm{NH}) ; 7.40-7.60(3 \mathrm{H}, \mathrm{m}) ; 7.70-7.80(2 \mathrm{H}, \mathrm{m}) .{ }^{13} \mathrm{C} \mathrm{NMR}$ spectrum, $\delta$, ppm: 18.7 (Me); $19.3(\mathrm{Me}) ; 20.9$ (COMe); $29.8\left(\mathrm{CHMe}_{2}\right) ; 54.0(\mathrm{CHN}) ; 64.5\left(\mathrm{CH}_{2} \mathrm{O}\right) ; 126.8(\mathrm{Ar} 2 \mathrm{CH})$; 128.6 ( $\mathrm{Ar} \mathrm{2CH}) ; 131.5$ (Ar CH); 134.6 (Ar C); 167.3 (NCO); 171.4 (OCO). Found, $m / z: 250.1449[\mathrm{M}+\mathrm{H}]^{+}$. $\mathrm{C}_{14} \mathrm{H}_{20} \mathrm{NO}_{3}$. Calculated, $m / z: 250.1443$.

(S)-2-Benzoylamino-3-phenylpropyl phenylacetate (8c). A solution of oxazoline $5 \mathrm{c}(1.50 \mathrm{~g}, 6 \mathrm{mmol})$ in dry toluene $(80 \mathrm{ml})$ was stirred at RT while benzoyl chloride (0.69 ml, $0.84 \mathrm{~g}, 6 \mathrm{mmol}$ ) was added dropwise. After stirring for $72 \mathrm{~h}$, the mixture was evaporated and the residue was triturated with diethyl ether to afford the title compound $(0.73 \mathrm{~g}, 31 \%)$ as colourless crystals, mp $122-$ $123{ }^{\circ} \mathrm{C}$. IR spectrum (ATR), v, $\mathrm{cm}^{-1}: 3292,1720,1638$, 1537, 1263, 1152, 1011, 694. ${ }^{1} \mathrm{H}$ NMR spectrum, $\delta$, ppm $(J, \mathrm{~Hz}): 2.79(1 \mathrm{H}$, half $\mathrm{AB}$ pattern of $\mathrm{d}, J=13.6, J=8.2$, $\left.\mathrm{CH}_{2} \mathrm{Ph}\right) ; 2.96(1 \mathrm{H}$, half AB pattern of d, $J=13.6, J=5.8$,
$\left.\mathrm{CH}_{2} \mathrm{Ph}\right) ; 3.67\left(2 \mathrm{H}, \mathrm{s}, \mathrm{COCH}_{2} \mathrm{Ph}\right) ; 4.16(1 \mathrm{H}$, half $\mathrm{AB}$ pattern of d, $\left.J=11.2, J=4.0, \mathrm{CH}_{2} \mathrm{O}\right) ; 4.21(1 \mathrm{H}$, half AB pattern of $\left.\mathrm{d}, J=11.2, J=5.6, \mathrm{CH}_{2} \mathrm{O}\right) ; 4.55-4.65(1 \mathrm{H}, \mathrm{m}, \mathrm{CHN}) ; 6.19$ $(1 \mathrm{H}$, br d, $J=8.4, \mathrm{NH}) ; 7.15(2 \mathrm{H}, \mathrm{d}, J=8.0) ; 7.20-7.35$ $(8 \mathrm{H}, \mathrm{m}) ; 7.41(2 \mathrm{H}, \mathrm{t}, J=8.0) ; 7.50(1 \mathrm{H}, \mathrm{t}, J=7.0) ; 7.60$ $(2 \mathrm{H}, \mathrm{d}, J=7.2) .{ }^{13} \mathrm{C}$ NMR spectrum, $\delta, \mathrm{ppm}: 37.4\left(\mathrm{CH}_{2} \mathrm{Ph}\right)$; $41.5\left(\mathrm{CH}_{2} \mathrm{Ph}\right) ; 50.2(\mathrm{CHN}) ; 64.8\left(\mathrm{CH}_{2} \mathrm{O}\right) ; 126.8(\mathrm{Ar} 3 \mathrm{CH})$; 127.3 (Ar CH); 128.5 (Ar 2CH); 128.66 (Ar 2CH); 128.69 $(\mathrm{Ar} 2 \mathrm{CH}) ; 129.2(\mathrm{Ar} \mathrm{2CH}) ; 129.3(\mathrm{Ar} \mathrm{2CH}) ; 131.6(\mathrm{Ar}$ $\mathrm{CH}) ; 133.8$ ( $\mathrm{Ar} \mathrm{C}) ; 134.1(\mathrm{Ar} \mathrm{C}) ; 136.8(\mathrm{Ar} \mathrm{C}) ; 166.8$ (NCO); 171.7 (OCO). Found, $m / z$ : $374.1745[\mathrm{M}+\mathrm{H}]^{+}$. $\mathrm{C}_{24} \mathrm{H}_{24} \mathrm{NO}_{3}$. Calculated, $m / z: 374.1756$.

\section{R E F E R E N C E S}

1. Oda, M.; Morimoto, K.; Thanh, N. C.; Ohta, R.; Kuroda, S. Heterocycles 2003, 60, 1673-1680.

2. Aitken, R. A.; Henderson, S.; Slawin, A. M. Z. J. Sulfur Chem. 2018, 39, 422-434.

3. Zhou, A.; Pittman, C. U., Jr. Synthesis 2006, 37-48.

4. Allen, P., Jr.; Ginos, J. J. Org. Chem. 1963, 28, 2759 2762.

5. Aitken, R. A.; Armstrong, D. P.; Galt, R. H. B.; Mesher, S. T. E. J. Chem. Soc., Perkin Trans 1 1997, 935-943.

6. Tomalia, D. A.; Paige, J. N. J. Org. Chem. 1973, 38, 422-430.

7. Zhou, A.; Njogu, M. N.; Pittman, C. U., Jr. Tetrahedron 2006, 62, 4093-4102.

8. De Silva, H. I.; Song, Y.; Henry, W. P.; Pittman, C. U., Jr. Tetrahedron Lett. 2012, 53, 2965-2970.

9. Huneck, S.; Porzel, A.; Schmidt, J.; Follmann, G. Z. Naturforsch., C 1992, 47, 785-790.

10. Achari, B.; Pal, A.; Pakrashi, S. C. Ind. J. Chem. 1974, 12, 1218-1219. X-ray cpd first mention in lit as deriv of natural product

11. Naidu, P. P.; Madakka, M.; Rajesh, B. Asian J. Pharm. Clin. Res. 2014, 7 (Suppl 1), 15-18.

12. Ohshima, T.; Iwasaki, T.; Maegawa, Y.; Yoshiyama, A.; Mashima, K. J. Am. Chem. Soc. 2008, 130, 2944 2945.

13. Shibata, S.; Matsushita, H.; Kaneko, H.; Noguchi, M.; Saburi, M.; Yoshikawa, S. Bull. Chem. Soc. Jpn. 1982, 55, 3546-3551.

14. Dalko, P. I.; Langlois, Y. J. Org. Chem. 1998, 63, 8107-8117. 